


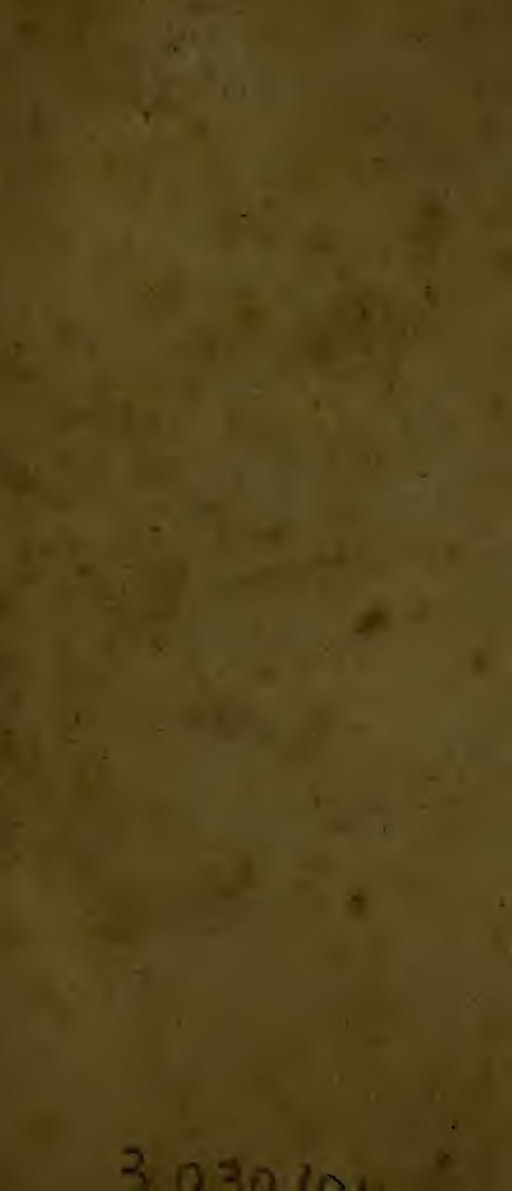


1. -

a

1

te 


\section{England's Path}

\section{T O}

Wealth and Honour,

$$
\text { I N A }
$$

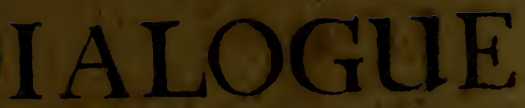

Betwcen an'

ENGLISH-MAN

A N D A

-DUTCH-MAN.

L U K E V. 4 .

anch out into the deep, and let down = your Nets for a draught.

Printed, 1700.

\section{$L O N D O N$ :}

Roprinted, in the Year. 1707 


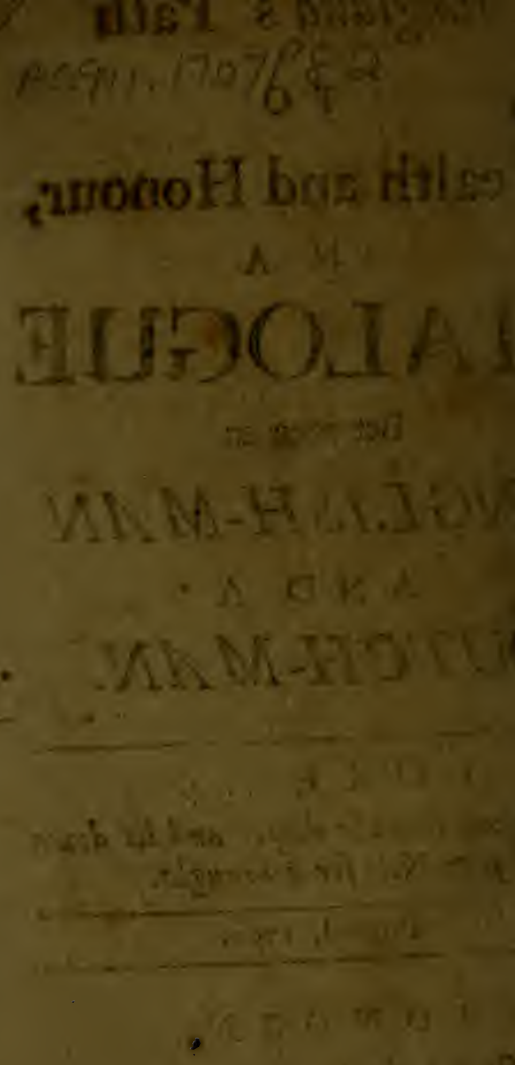

궁

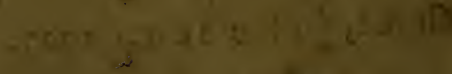

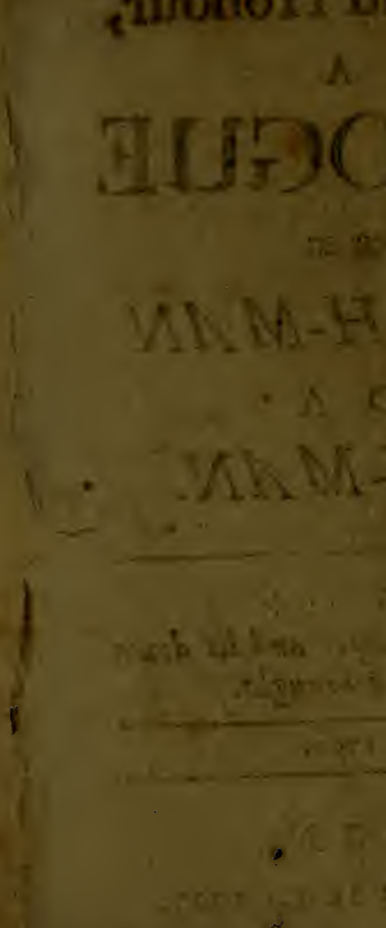




\section{The Molt Noble}

\section{HOMAS Duke of LEEDS,} Marquifs of CARMARTHEN,

\section{Earl of $D A N B Y$, \\ Vifcount LATIMER,}

Baron Osborn of KIVET()N;

$$
\text { A N D }
$$

N N IGHT of the moft Noble Order of the GARTER,

GOVERNOUR of the Royal Filhery of ENGLAND.

May it pleaje your Grace,

TO Perfon having fpent more Money and Pains than Four Grace, to Re-eftablifh the Fifbery of England; I prefume to Dedicate to you the following Dialogue: Not tliat I have the A. 2 Vanity 
vamity to think this my poor Mite can make any Addition to your Grace's Great Treafure of Knowledge: But as believing the Fact therein contain'd, fo true, it might lafely appear before the Belt of Judges.

With all Refpect I am, Tour Grace's

\section{moft Humble}

$$
\text { moft Faithful }
$$

DToritill-

$$
\text { moft Obliged }
$$

\section{and moft Obedient Servant.}

James Puckle. 


\section{P REF ACE.}

HE Highlands of Scotland, Wales, Bifcay, Switzerland, and other Countries (not worth conquering) continue ftill in Pofeefion of their Abarigines: Wereas, England being a Country (as was. (elid of the Tree of $P$ aradice) good for Foods eafant to the Eyes, and to be defired, hath en polfes'd by Five Several Nations, and veted by many more.

Yet view its Coafts, they'll appear Bold, anst thinly Inbabited, and the Civil Wars of Ifand baving occafioned the domoliffing of its ftrong Holds, in cafe of Attack, bow com we be defended againft Foreign preer fult nemies, but by a Naval Pomer?

Allowing us Mafters of more $T$

than any of our Neigbbours. What Secnrity can a numerous Navy afford, if Mar-7 riners be wanting?

Whether England wants Mertiners befs appears by our turning 'em o're from Ship to Ship, by our long, long Embargoes, and yet excefive Charge in Prefing, and by fo maxy of our Ships being loft (during the late War) for want of their Complement.

Nor can the Number of our Seamen be readily Encreaft, without Eftablifhing a Fifhery. For Men of War and MerchantA 3 


\section{HR E F C E}

men fpend many Marriners, and breed Few, the great and beft Nurfery for Seamen is the Finhery; where each Dogger brings up (it may be ) Six, Eight, or Ten, new Men every $r_{e}$ ar, and the Fifsermens Bufinefs lying where our Ship's Danger lies, makes them know how the Sands Bift, where the Rocks and Shelves are; Confequently moft able Coafters and admirable Pilots.

Befides by frequent riding out great Storms in $\int$ mall Buffes and Doggers, Fifhermen be. come so fteeled and babituated to Danger, that in Tempefts and Engagements they soork Wonders; and the Fifhlying upan our own Coafts, the Men we employ to catch them (though out of His Majefties Pay) will be ever at Hand, and fo ready for Service, as to make our matchfulleft Enemies despair of furprizing us.

Again, "A due Care for our Poor, is "an AEt of great Civil Prudence and Poli"tical Wifdom, for Poverty

1.C. I. Hale in "in it felf is apt to Emafcuhis Difcourfe touchirg Provifion for the Poor.

"late the Minds of Men, "or at leaft it makes Men "tumultuous and unquiet; "mbere there are very ma"ny Poor, the Rich cannor "long or fafely continue fuch; nece]Jity ren- 


\section{PRE EACE.}

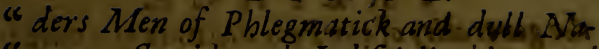
"tuires, Stupid and Indifoiglinable, rined

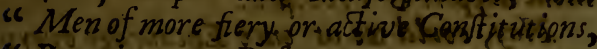

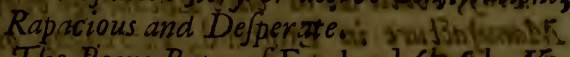
The Poons Rates of Eingland (boridas Ka-

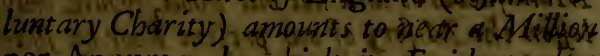
per Annum, by mbich, its Evident intiat vaft Numbers of Beggexs and Idle Perfons live upon the Publick moitbout veturn of Lor bour for their Bread.

Now Beggars Childrem (if weot de-

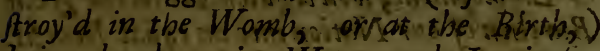
being bred up in Waint and Laziness, become of -zinhealthfut. Bodies, and moric then ordinary subject to mayy loathfome Difeafes, whereof abundance die in theswe: tender Age; and fuch as gettein to ripere? Years, by idle Habits contralted in thein Youths, are rendred for eiver unspt and wh difpofed for Labour, and Jerve only to figek. the Kingdom with Theves and Begaers? that without a due Care for Relief of oun Poon in a way of Induftry, they'll daily Encreasc.

Suppose, to employ our Poor any one itidnufacture be encouraged: It may perchance remove the prefent Trade of one City or County to another, and occajionex fuch Complaints as thel Button-Makers (not long fince) made ayainft Cloth Buttons, yet learve A 4 


\section{$P R E F \subset E$}

the generality of our Poor deftitute of a conve. nient Support $\sigma^{\circ}$ Provifion.

- Nay, could we at once Encourage every Mamufacture in England, encreajing our Manufaetures and not our Food, mould only leffen the Mifery of our prefent Poor by Shas ring it amongft all the People of the Kingdom. The moft effectual Expedient then to employ our Poor, is to Eftablifs a Fifhery; which by affording them at once both Food o Employment, wout d quickly turn the great Burtben of our Nation into an equal Benefit.

Muchmore might be aid to this Purpofe; but at prefent Ifhall only add that witbin thirty rears paft, our active Neigbbours the French have encreafed their Navigation to aProverb; given Europe much difquiet, cond coft England (inparticular) abundance of Blood and Treafure. But bad not Englifhmen been guilty of more than Spanifh Roath in not putting forth their Hands to take that Rich bleffing, (the Fifhery) which Providence by placing upon our Coafts, courts us (as it were) to receive, all our Savereigns (as well as Queen Elizabeth,) might have bounded the Numbers of the French Fleet, and been lyy the blefjing of God

\section{Pacis Europæ Arbitri,}

Maris Domini \& Vindices. 


\section{(9)}

A N E W

\section{I A L O G U E}

\section{Between an}

\section{ENGLISH-MAN}

A N D A

\section{DUTCH-MAN.}

Dutch-Man,

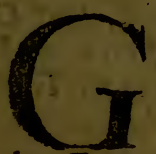

$0.0 D$ Morrom
Friend, what art Friend, wh
mufing on?

Englifh - Man,

Confidering the Extent of thefe your Dykes, I was thinking what exceffive Charge and Pains Holland is yearly at to defend it felf againft invading Waves: Whereas the Sea that encircles England (Barrier like) fenceth it againft Surprize ind Ravages, exempts us from the Charge ind Terrour of Garrifons and Fortificatipns, and (with our Floating Caftles) 


\section{(10)}

continues to us that quiet Liberty and Security the reft of Europe more or lefs have loft.

D. England indeed is fenc'd in by the Sea, but ( Money is the Sinetrs of War and) bappier Holland hath a Main Ocean of Wealth to Defend it.

$E$. The cold Winds (being moiftened by the Vapours, or.foftned by the warmith of the Seas motion before they reach our Inand) are lefs fierce, and the Air is far more Mild and Temperate (if not more Healthy) than any part of the Continent under the fame Climate; fo that we have no necefitty for Grottoes in Summer, or Stoves in Winter.

D. In my Opinion, that Country is ftill Happicft thit is ftored with the Richeft gromtls and products for Traffick and Commerce, and the Air ever beft where moft Money is ftirring; for Poverty and Want will render People vinbealt by in all Climates. E. England abounds with Mines, Rocks, Pits and Quarries of (a) Alablaiter, (b) Antimony, (c) Ardois, (d)

(a) Darbyjhire, Nottingbanghire, Staffordßhire. (3) Darbylbire, (c) Cornwall, (d) Cumberland Black 
Blacklead, (e) Chalk, $(f)$ Chriftal, $(g)$ Tobacco-pipe-Clay, (b) Coals of divers Sorts, (i) Copper, (k) Fullers-Earth, (l) Freeftone, (m) Iron, (p) Lapis Calaminaris to make Brafs, (o) Loadftones, ( $p$ ) Lead, (q) Marble, ( $r$ ) Milftones, (s) Plaifter (harder than that) of Paris, $(t)$ Potters-Oar, (u) Slate, (w) Salt, (x) Steel, (y) Tinn, (z) Whetitones, \&o.

Upon its Coafts are found (a) Amber, (b) Ambergrife, (c) abundance of Cop-

(e) Suffex, (f) Dirbybire, (g) DorfetBire, (b) $C$ mirthenffire, Cumberland. Durbam, LancaJhire, Lei:fterlhire, Noribumberland, Sbrophise, Staffordfhire, rorkfhire, (i) Cornwall, Cumberlard, Darbyfhire, Staffordbire, Yorilhire, ( $(k)$ Bedfordfliere, Surry, (l) Dorfethire, (m) Darbyhire, Durbam, Gloucefterffire, Hampflire, Shrotfire, Stafford(bire, Vivarmickflkive, (n) Somerfetfire, $(\rho)$ Divonhire, $(p)$ Cirdigarflire, Carmartbenghire, Darbyghtre, Dvonflite, Durbam, Staffordfhire, rorithire, (1) Dirbyghire, Dorcet(Rire, ( $r$ ) Anglefee, Cheffire, Darbyghixe, Flinthire, (s) Nottingbamfbire, (t) CarmiartbenSbire, (u) Cornwoall, (w) Cbefpire, Cumberland, VVorcefterbire, $(x)$ Gloucefterlbire, $(y)$ Co.nwall, Devonhhire, (z) Darbyghire.

(a) Norfolk, (b) Cornwal, (c) VibiftabieShallow, 
perice Stone, (d) Jet, (e) Pearls, $(f)$ fine Pebles, tranfparent like Diamonds; alfo Flint Varrack, Orc. to make Glafs: Befides (not to mention the Rich Commodities yearly Iniported from its Fruitful Plantations, that are to it as fo many Mines of Treafure, ) England affords Plenty of Corn, Cattle, Fowl, Fruits Pulfe, Leather, Wool, occ. Whereas, Holland produceth nothing but a few IIsps, Madder, Butter and Cheefe.

D. The whole Product of your Ifland is nothing when compared to the $(\mathrm{g})$ Golden Mines of our Provinces, which bave yielded us more Treafure than the Mines of Potofi, or both Indies to Spain.

$E$. The Golden Mines of your Provinces; Pray where do they lie?

D. In Neptunes Store-pond, which the Englifh call their Seas.

$E$. Our Famous Edgar with a Navy of Four Hundred Sail, vindicated his Dominion on our adjacent Seas, and Records mention his Succeffor Canutus to have laid

(d) Norfolk, (e) Cumberland, (f) Cornswall, usloucefterfhire.

(g) So the Dutcb in a Proclamation 1624 , Niled the Finhing Trade.

that 


\section{(13)}

that ancient Tribute called Danegelt; upon all (whether Strangers or Denizons) trading on our Coafts or Seas.

Egbert, Atthred and Ethelfred, all ftiled themfelves Supream Lords and Governours of the Ocean, furrounding the Britifh Shore.

King Fobn (b) challenged the Honour (or rather) Duty of the Flag, univerfally. paid us, not barely as a Civility, but as a Right (debità Reverentia) Acknowledging our Title and Dominion.

The Famous Record entituled Pro bominibus Hollandie, fhews how Obfequious your Anceftors were, not only in acknowledging (i) Edward the Firft's Dominion on the Sea, but craving his Prorection and Permifition to Fifh on the Coaft of England: And had not the Sovereignty of the Britißh Seas in fact been in the Crown of England, why did the (k) Earls of Holland petition Edward the Third (and the (L) French our Henry the Sixth) for leave to Fin therein? And

(b) Anno 1200. (i) Anno 1295.(k) Rot. Par: 3. Ed. ift. numb, 5. (l) Rot Par, 22, Ed. IVtb, wmb. 2. 


\section{(14)}

why did your $(m)$ Skippers ufe to purchafe Licenle from Scarborough Caftle, before they prefumed to caft a Net upon the North Coafts of Engl znd? Wherefore did $P$ bilip the Second of Spain, $(n)$ obtain Licenfe of Queen Mary for his Subjects to Fifh upon the North Coafts of Ireland for the Term of Twenty one Years, for which was yearly paid One thoufand Pounds into the Exchequer of Ireland, as by the Records appeas?

D. A Fig for your mouldy Records: I fay the Sea is as free to F. Ib in as.

E. --As the Roads of Hollind are $t$ Travel in, where both Natives and Fu reigners are forced to pay paffage $G$ belt.

D. Don't Interrupt me, Sir ; Ifay, the Sea is as free to $F: f_{3}$ in as the Air to Breath in; who doubts it, may read our Great Hugo Grotius's Mare liberum.

E. Grotius in his Sylva upon the Inauguration of King Fames (before he was perverted by the Importunities of his Country Men, ) fpeaking his Thoughts freely fay's,

Tria Sceptra profundi In magnum coiere Ducem.

(m) Canden's Brittania, (n) 1552 . 


\section{( Is)}

The Rights of the Englifh, Scotifh and IrifhSeas, are united under one Scepter; neither is he fatisfied with that bare Profeflion:

Sume Animos a Rege tuo qui dat Fura Mari.

Take courage from the King that giveth Laws to the Seas.

And in the fame Book, in the contemplation of fo great a Power, he concludeth,

5. Finis hic eft qui fine caret, \&c.

This is an End beyond an End, a Bound that knows no Bounds, which even the Winds and Waves muft fubmit to.

And if you remember when King Fames obferved your Encroachments, he enjoyned his Ambaffadour Sir Dudley Carleton to Expoftulate the matter with your States, as may be feen in Mr. Secretaries Letter, bo) wherein he tells them, "That unlefs they fought leave from his "Majefty, and acknowledged his Right,

(0) 21 Dec. 1618 


\section{( 16$)$}

"s as other Princes had done, and did, it

" might well come to pafs, that they " who would needs bear all the World

"s before them by their Mare Liberum,

" might foon endanger their having nei-

" ther Terram, nec Solum, nec Rempubli-

"cam liberam: So much did that Wife Prince difdain to be wrangled out of the Ancient Rights and Regalities inherently annexed to his Crown, by the fubtle Arguments of Wit and Sophiftry.

D. Don't tell me of King James, I say, that the Sea is free for every Body, and defy you to gew the Contrary.

$E$. Why then do the Venetians exercife Dominion in the Adriatique, and the Tufcans I.ord it in the Tyrrbene Seas? How comes it to pafs that all your Skippers pay Toll to Denmark for paffing the Sound, and to Swedeland for failing in the Baltick? Wherefore doth the Republick of Genoa, let to Farm the Fißhery for Teunies in their Neighbouring Seas: And the Emperour of Rufjia compei all Fifhermen (within his Seas) to pay him Tribute; How is't that the like is done by the Duke of Medina Sidonia in Spain, and by all the Princes of Italy bordering on the Seas? Nay, wherefore do the Dutch ftile themfelves 
felves Lord's of the Southern Seas, and allow far lefs Liberty in: India than they take upon the Englifs Coafts.

But to wave this Difpute: 'Pray Sir, how many Labourers have you in your Golden Mines as you call'd 'em?

D. Upon taking an Account of the Several. Trades and Employments, by which the Dutch fubfifted (in order to find which beft deferved the Protection and Encouragement of the Publick,) it appeared, that in Anno. ins:. The Subjects of the States General were (p) Troo millions, Four bundred and Fifty thoufand, of which (befides thofe employed in the Inland Fifhery,) Four bundred and Fifty thous and were then maintained by Filling at Sea, and the Traffick depending thereon; fince which time we have much ens creafed the Numbers of our Fifling Buffes and Doggers, to the great Encouragement of or Navigation, and all Trades depending $m$ the Fifhery.

$E$. Which are they?

D. Anchorfmiths, Bakers, Ballaftmen, Basket-makers, Blackfmiths, Browers, Butphers, Carpenters, Caulkers, Clapboard-

(p) Pol. Gron \& Maxims Van Holl. Page 43. Splitters, 


\section{(18)}

Jplitters, Compass-makers; Coopers, Duckweavers, Hemp-dreflers, Hook-makers, Hoop Nitters, Foyners, Line-makers, Mar: ripers, Maft-makers, Net-makers, Nettannersi Plummers, Pully-makers, Pumpmakers, Rope-makers, Sail-makers, Sanoyers, shipicibandlers, Ship-wrights, T allowchandlers, Thread and Tmine-Spinners, \&c. to the no small Profit of the Makars and Venders of all Materials, Tools and Utenfits ben Longing to thofe Trades, and of all Tradesa men that make or Sell Culinary Wares, Bed ding, Cloathing, \&x. for Mariners; to mbich may be added, Packers, Tollers, Drefers and Couchers, to carry, fort, and make the Herring lanful Merchandize, al So Porters, Carmen, \&c. In a Word, you can bardly caft an Eye, upon any fort on condition of Pecple, but profit by our 'Fifhery, and the Community most of all.

$E$. Pray where, and at what times of the Year do you fith for Herrings?

D. In the beginining of June, the Herring rifing about two Leagues of Cranehead (the outermoft part of Bratio-iound, ) ftay there about fourteen Days, thence go te Fare ry Ifands, (Seaven Leagues to the Southward of Shetland, ) round which they remain one and twenty Days, thence to Buf- 


\section{$(19)$}

finnels (about thirty Leagues to the Southward of Farry IRand,) the Fißjing place is called Buffin-deeps, and is twenty Leagues to the Northward of the Frith, mahere the Herring abide about fourteen Days, and in the Fifling ground under Chivit-hills and Chivit-chace about fourteen Days, thence we follow them to the Dogger-bank, where theyftay about thirty feaven Days; about the beginning of September, they come into Yarmouth Seas, phere they continue nean Seventy Days, from whence they fall to the Southward, followed by Small Fifjermen, it being dangerous for Doggers.

$E$. What quantities of Finh are yearly taken by the Dutch?

D. About (q) Threc bundred thouf and Lafts.

$E$. This confirms Sir Walter Ramleigh's Obfervations prefented to King Fames, $(r)$ and hews that the Learned Sir Fobn Burroughs, in his Sovereignty of the Brittifh Seas, upon good Grounds affirmed that the Fith yearly taken by Strangers upon our Coafts, did amount to (s) above

(q) L. v. Aitzma. Anno 1653.

(r) Anno 1633.

(s) Page 140. 


\section{(20)}

Ten millions of pounds Sterling. But pray Sir, where have you vent for all your Fifh?

D. At Artois, Brabant, Bremen, Cleveland, Cologne, Dantzig, Denmark, Elbin, Embden, Flanders, France, Frankford, Germany, Gulickland, Hamburgh, Henault, Holftein, Italy, Liefland; Lithuania, Lubeck, Nerva, Norway, Poland, Pomerland, Portugal, Pruffia, Quinsbrough, Revel, Riga, Ruffia, Spain, Stade, Stratten, Swedeland, \&c.

$E$. Are you never afraid of glutting the Markets?

D. No more than we are that Pecile will leave eating, great part of the tradis Horld being yet unferved, wbich is the Re an we yearly fo much encreafe the Number of our Doggers.

$E$. What Returns are made for your Fifh?

D. Allum, Armour, Baratees, and other Frankfort 'Commodities, Brandy, Bullion, Clapboard, Coin, Copper, Corn, Currants, and atber Grocery Wares, Damasks, Dealboards, Dollars, Flax, Fruit, Furrs, Fuftians, Glafs, Hemp, Honey, Hulfop, Iron, Lace, Linnen, Mil- 


\section{$(2 \mathrm{I})$}

tones, Oyl, Pitch, Plate, Potafh, Prunes, Rafies, Rofin, Sarfenets, Sattins, Silks, Skins, Steel, Tapftry, Ter, Timber, Velvets, Wainfcots, Wax, Wines, and other things in abundance; the exporting of which Commodities again to other Countries, gives our Ships full Employment, fo that they need not go in Ballaft to Jeek Freight, but by the Profit of outward bound Voyages, are enabled to Serve Foreigners So cbeap, as to render us the common Carriers of the World, confequently Mafters of the moft.certain Profit in Trade; for when Ships arrive Jafe in Harbour, tho' Merchants happen to lofe by their Goods, Owners and Seamen are paid Freight and Wages.

Befides by continual Bartering of fuch $E x$ ports, Holland is. rendered the mighty Storeboufe, and Empory of all Foreign Products and Manufactures, from whose infinite Mifcellany of Goods its Inbabitants are compleatly furnifhed with fuch fortable Wares, as enables them to trade from Port to Port without danger of glutting Markets. And thas as our Fijhery bath encreafed our Trade and Navigation, conftant Imployment bath ftill made Foreigners flock to us in fuch Numbers, that out of our Multitudes, fupplying (from time to time) the loos 


\section{2)}

lofs of $\int_{0}$ many Lives as the Change of $\mathrm{Cli}$ mates, Succeffes againft the Por tugefe, and Victories againft the Indians have cust us; we have forced Treaties of Commerce, ex: ilufive to all other Nations: Built Forts upon Straits and Paffes that command the Entrances into Places of great Traffick; monopolized all the Spice Trade, and migbtily advanced towards Engrofsing the whole Commerce of the Eaft Indies.

E. Well may you boaft, that Amfter dam is Founded apon Herring Bones; and no wonder that notwithftanding your fo frequent and chargeable Wars ever fince your Revolt from Spain, there is hardly a Beggar in your Streets.

But if in Holland, which contains not above Five millions of Acres, leits Bogs and Sandy-downs excluded.

Holland, where you have no Minerals, and where it is in vain to dig for any thing but Turfand Clay.

Holland, where you have no Tree but what you planted, nor Stone but what you brought thither.

Holland, fo much lower than the Ebbings of the Tides and Rivers, that at vaft Expence you are obliged with Mills to drain the very Floods occafioned by Rain.

Holland, 


\section{$(23)$}

Holland, where notwithftanding your ontinual Charge (as was faid) in repairng Banks and Dykes; frequent Inundaions deftroy Man and Beaft for feveral Miles together, and then vaft Sums (and whole Years) are fpent e're the Land can pe regained.

Holland, where the Eaft Winds comng to you o're a mighty length of dry Continent, extream Cold, and long Winers, put you to the expence of much Fire, Candles, Food and Rayment; and to great charge and pains in houling and fodjering your' Cattle, all which time they (living on dry Food) yield little Milk.

Holland, fo expofed to bleak Winds, that blaft the Bloffonis of its Trees, and Storms that fhatter off e're ripe their Fruit.

Holland, where that little Arrable Land you have, lying generally on Sand or light Bottoms, requires much Soil, and where Seed-tinie is fo thort, that unlefs it be exactly nicked, no Profit can be reaped; for when the Seed rots in the Ground (as by great Rains it frequently happeneth,) the Seafon is generally paft before it can be Sown again.

Holland, 


\section{$(24)$}

Holland, whore whole Product is fearc fufficient to ferve $(t)$ one Eighth part its Inhabitants, confequently the reft ar obliged to purchafe the fo neceffary Coin modities, Food and Rayment, of Neight bouring Countries at the Rates they cat get then?.

Holland, whofe Territories extending upon powerful Neighbours, to defend it Frontiers, and draw out a War in length by Sieges, in order to determine it, by force of Money rather than of Arms; you are obliged to be at vaft Expence in Fortifications and Standing Troops, to defend them even in the time of the pro: foundeft Peace, for Inftance Anno I 670 After all Reforms, you had Ten Regi ments of Horfe and Nineteen of Foot making together Twenty fix thou. fand Two hundred Men, the conftan Charge of which Forces was $55628 \mathrm{I} l$ Sterling per Annum.

I fay, if in Holland, naturally loaded with thefe Difadvantages and Misfor tunes, and all their ill Confequences:

(t) Pol. Gron \& Maxims van Holl. Page 44. 


\section{(25)}

notwith ftanding you are $(u)$ Bridled wit's bard Laws, terrified with severe Executions, environed with Foreign 'Forces, and opprefJed with the moft cruel Hard/sips, and variety of Taxes that wore ever known under any Government. Your People are become fu numerous and wealthy, by Finhing upon our Nortbern Coafts.

Did we in England diligently apply our Selves to the Fifhing Trade, what a coninual Sea-Harveft night we reap, whofe Coafts fo abound with Cod, Hake, Conger, Whitings, Scate, Sprats, Soals, Oyters, Salmon, Pilchards, Turbets, Thornpacks, Mackerel, Herrings, or Ling, all the Year long.

D. Why, e'en juft fuch a Sea-Harveft as be Hamburgers did (who after five or $\int_{2 x} x$ ears Trial to imitate us in the Herringifhery) found to their Coft we ftill out-did bem, and so we foall you.

$E$. The Reafon why you out-did the Hamburghers, was, becaufe they were early Frozen up (w) fomewhat longer han you, but feeing by that Start you ould out-ftrip them, furely we need not

(u) Sir William Temple's Obfervation on the EnitedProvinces, (w) Lex. Mercator. Fol. $17 \mathrm{t}$. 


\section{$(26)$}

fear the Goal; who (befides what has been faid,) have in Fifhing many more Advantages of you, than ever you had of the Hamburgers.

D. The generality of your Countrymen are of anotber Opinion.

E. I a m not Ignorant what Induftry has been uled to poyfon my Countrymen with an Opinion, that only Dutch-men can thrive by Fifhing: But upon examination, it will appear,

- The Dutch have above an Hundred Leagues to Sail before they come to the Herring Fifhery, which is only in the Britifh-Seas, and when there, niuft lie at the meecy of the Winds for want of a Port to Friend, and in cafe of Unloading, have as far back again; which takes up a great deal of Time, hinders Bufinefs, and endangers the lofs of their Markets : Whereas, in England we have the Fifh uponi our own Coafts, fo near our Shoars, that in cafe of Storms, Unloading, taking in of Provifioms, or the like, it is but four or five Hours work (commonly not fo much) to recoven an Harbour, and without lofs of time put to Sea again; the work of Unloading, Repacking, and fending our Fifh to Market, going on in all Weathers.

D. And 


\section{(27)}

D. And bave not we Dogger-Bo.zts to ake off our Fifh at Sea, and refurnifs the Whermen mith Cask, and otber Necelaries. $E$. Yes, sir, and you have the charge ind rifque of thofe Dogger Boats too (both which the Englifh fave,) after all, if it happens to be a Rowling Sea, you canlot work, but muft lie by and wait for a Calm.

D. What other Advantages can you boaft? E. England, hath many convenient Iide-haven-ports, as at Full, Harwich, and Holy Illand to the Nortbward, and Dover, Rye, Portfmouth, Southampton, Comes, Weymouth, Dartmouth, Catwater, Hamose, Fompy, Falmouth, Hilford, Scil$b y$, and Milford, Weltwpard, where at low Water all of them are fmall Ching:le or * Wrd Sand; fo that our Veffels.na y eafily haul a fhore, and Waif and Tillow at Pleafure; nor are Creeks and commodious Places wanting in England to lodge our Buffes and Doggers fafe when not employed, fo as to prevent wear of Cables, charge of Watching, danger of Fire, $\sigma^{2} c$,

D. What els a,
E. The Shores of England are bold, its Coafts high-land, eafily difcovered, feveral of our Cape-lands oppoffte to $\mathrm{B}_{2}-$

France 


\section{(28)}

France and Holland, make Eddy-Baycs, whofe depth of Water is mean, as fix, eight, ten, or twelve Fathom, the Tides (on our Coafts) are fmall Anchor hold, generally ftiff Clay, Chalk or hard Gravel, fo that we need not dread Winter Storms, befides the Advantage we have of lying in a moderate Cliniate, and in the very Center of the Trade of Europe, affords us opportunity of fending to Forreign Parts, from divers of our Ports, at all Seafons of the Year: Whereas, the Coafts of Holland are extreamly Low, fubject to be Hazy and Foggy, have ma: ny Shoals and Sands, fome of which lie fo far. off at Sea, that frequently Ships are Stranded before they fee Land; its Port. are bad, and often choaked up with Quick-fands; its Havens yearly frozet up two or three Months together: Ano the North-meft Wind (ufually blowing the greateft part of the Year) make Holland a Lee, and England a Weather fhore, fo that (oft-times) whil'ft you ar Wind-bound or Frozen dip at home, w can fupply the Markets abroad.

Befides, wanting wood at reafonabi Rates, you cannot fhare with us in the Red-herring Trade. 


\section{(29)}

As for Pilchards, they cannot be wel! fured, unlefs brought freth on Shore, and peing taken on our Coafts, will be Stale 're they can be carried to Your's.

Not to mention our Rich New EnglandFishery, our Weftern Ports are incomparably fituated for the Nemfoumd-Land Fishery, and the Country it felf belonging to the Crown of England, you can have ho footing there.

Near the Pile of Foudray in Lasicafinice, and, in feveral other Places along the Shores of Wales, we can Fifh even without the Charge of Doggers, for by cnly fetting Nets on the Sands at low Water, great quantities of Herrings are taken next Tide of Ebb.

D. Thofe Herrings on tise Coafts of Lancafhire (coming nemly out of the Ocean) are fo fat they will not take Salt kindly, GMVi Sequently are apt to Reaft.

$E$. We now find by Experience, that fat Herrings being preffed and cured like Pilchards, take Salt kindly, and yield ftore of Oyl; to the great Encouragement of our Ship-wrights, Curriers, Soap-boylers, Ecc.

D. How chance this Method was not found out fooner?

$$
\mathrm{B}_{3} \quad \text { E. Dies }
$$




\section{( 30$)$}

Dies Diem docet; thofe noble Salt rucks in Chefsire, (fufficient to fupplyall Europe) have not been many Years difcovered:

Befides, of a Coar abounding in ShropBire, mach Pitch is now made of fo Ex cellent a Nature, Heat only caufeth it to penetrate deeper into Plank, and Cold cannot make it crackle off; both which are Advantages Holland can't pretend to.

D. What more?

$E$. The Cotfts of Wales abound with An; which as far excels other Wood for drying Herrings, as its Bark doth all others for tanning Nets: Nor do we in England (-as you) want Willow - hoops from Hamburgb.

D. Notwithftanding all the Advantages you speak of, your Chief Fifhing Towns, Yarmouth and Layftoffe, are bebolding either to us at Enckhuijfen, or the French at Diep, for Jelling them Nets?

$E$. Before the late War, they ufed to buy Saif Cloath of you too, but that now made at Fulbain, \&c. is brought to equal Perfection with your beft Hollands-Duck; and as for Nets, the Towns you mention, have thefe feven Years laft paft made moft they ufed; and who knows, but that 


\section{$(-3 \mathrm{I})$}

our Artifans (univerfally allowed the beft upon Earth for Improvements) maty in a little time as much excel you in thefe Things, as they out-do the Germans in fine Steel-works; which though they firft Invented, yet we now make and fell to them.

But feeing you talk of being beholden: I think you are beholden to us, for feiling you our Thames Lamprons where. with you bait for North Sea Cod, elfe you might go...... whiftle for'ens.

D. Have you any more Advantages of ous?

E. Upon Exporting our Fih, we have the Benefit of a confiderable Draw-back upon Salt.

D. If that's all, rather than fuffer that Tide of Wealt that fows in our Filhery to be Diverted to another Channel; no douldt but our States will allow the Dutch the like Encouragement. But nom you have totd me all your Advantages, I bope.

E. Excufe me, Sir, England afford: Timber, Jron and Hemp; whereas you are forced to purchafe thole Commodities in Foreign Countries.

D. Nevertbeless, we bave all Noval Stores in Barter for Herrings, which cofts us little but the trouble of haroling up out of 


\section{$(32)$}

the Sea, which being confidered, and bow much the catching fuch Herrings (by employing and encreafing our Ships and Marriners, adds to the Wealth and Strength of owr (ountry,) it conducetb far more to our Advantage, than if Holland bad Naval Stores of its own Product: Whereas, to purcbafe Eaft Country Wares, the Englifh are yearly forced to export much Coin, to the great exbaufting of their Treafure.

$E$. We do not (as you) depend folely upon the Eaft Country for Naval Store; no, in cafe of Exaction or Rupture, we can be fufficiently fupplied from our $A$ merican Plantations.

But if a Fifhery be Eftablifhed in England, what fhould hinder us from having. Naval Stores in Exchange for Herrings,as well as you?

D. Your White Herrings are not So bright and good as ours.

$E$. Whilft your Clapboard is floating from Germany, the Rbine draws out its Sap, and if we alfo foak the Corrofive Sap out of our Clapboard, which now difcolours and preys upon our Fifh, and like you, gip and falt the Herrings as foon as taken, they'll be every whit as bright, and good as Yours.

D. $W e$ 


\section{(33)}

D. We build Cheaper in Holland than you do in England.

$E$. Our Ships are much Stronger, and abler to brook the Seas, and will laft twice as long.

D. Our Vefels Sail with fewer Hands.

$E$. We have no reafon to envy you that happinefs, whilft (in proportion to your Tunnage and Number of Marriners) you yearly lofe (by undermanning ) far more Ships and Mens Lives than we, for which Reafon, in above three Parts of the World, our Ships yield better Freight; where then lies the Odds? Which were there any, could be only in Merchant-men, to carry our Fifh to Market: Doggers and Fifter Boats carry more Men to catch Fifh than are needful to Sail them :- And in the Greenland Trade, each Ship to Man their Shallops, when a Finhing, muft have Three times the Crew that can Navigate her. Were not this true, fince in building Englifs Shipwrights know no Mafters, furely we night eafily caufe our Ships to be built and manned after your Mode.

But fuppofing your Affertion true, if 5 all Ships that carry Corn to Y cnice, are permitted to Load Currans at Zmt : fo

$$
\text { B } 5 \text { all }
$$




\section{( 34$)$}

all Bottonis which Exported Englifh caught Fifh, might be allowed to return with a Loading of Naval Stores, without paying Alians Duty : That would fet us upon even Ground with you, as to the Bufinefs of our Fifhery.

D. Tmo thoufand Five bundred Perfons are bardly able in a woble rear, to make a Fleet of Nets for Five bundred Doggers: Nom England's many wafts and unimproved Lands, fheros it's not balf peopled, and of those in it,

\section{Confider,}

How many Women and Children do juft nothing, but fpend what ot bers get.

Horn many are meer Voluptuaries, and, as it were, Gamefters by Trade.

How many live by puzling poor People mith unintelligible Notions.

How many, by perfwadiug credulous, delicate and litigious Perfons, that their Bodies or Eftates are out of Tune or in Danger. How many by Trades of meer Pleafure or Ornament.

How many by Myfteries of Vice and $\operatorname{Sin}_{2}$ or in a lazy way of Attendance upon others, where then can you hope to find Hands to carry on your Fifhery. 


\section{( $3 i)$}

E. The Numbers of the Idle Perfons you mention, denote rather want of Bufinefs ui than= want of People : However, a full Enployment of the Hands we have, is certainly the beft way to get mure; for fuch as our Employment is for' Prople, fo many will our People be.

C: The far greateft Part of England's Droans, are ineither fo Young, nor yet fo Old or Decrepit, but that they may either turn Wheels, fpin-Twine, braid or beet Nets, cut Corks, caft Leads, make Herring Spits, Norfels, Swills or Baskets, Gip, Spit, Salt, Hang or Pack Herrings, or at leaft tend Fires to fnoak or dry them, pick Oakum, or the like; and, as a conftant Employmeht of our Poor, will bed cointinual Eafe and Consfort to thent, by a amuling and diverting them from thinking of their Poverty or other Mifery; fo will it alleviate the $\mathrm{Na}$ tions Burthen, and in fone meafure be a Re-peopling of us too, by adding fo many loft Hands to the Service-of the Publick.

In England, ? we have Numbers of French Proteftunts, who fled from Diep and the Coafts of Normandy, \&ec. (hred. to the Bulinefs of the Fi/hery from their 


\section{$(36)$}

Cradles) that (if fettled in our decayed Fifhing Towns) would as certainly make them Flourin as the Walloon and Burgundean Refugees, planted by Queen Elizabeth (w) at Nornvich, Canterbury and Colchefter, raifed them (then fo poor) Cities, to fuch great Trade, Riches and Plenty.

In England, we have no Sumptuary Laws: So that Mercers not foreknowing Fafhions, dare not lay out their Stocks tilt the Spring; at which time theirifudden great Demands render Journey Men fcarce, and oblige Weavers to draw in Numbers of Apprentices, who in few Months fupply the Trade of the Nation; when being turned off, many (like the Inhabitants of the Bath, Epfom, Tunbridge, \&c. who live by exacting on Strangers in Summer,) are ready to Starve for want of Employment before the next Spring.

Were a National Fi/hery Eftablifhed in England, our Gentry, by caufing their Footmen and Servants to rife early, and employ their idle Hours in making Nets, might not only reap the profit of their woork, but by accuftoming them to Bufinefs in

(w) 1568. 


\section{(37)}

their Youths, beget in them fuch induftrious Difpofitions, as would prevent (what now too frequently happens) their becoming Beggars, or worfe in Old Age.

The time of Labouring and induftrious People well Employ'd, is the beft Commodity of any Country; and were a Fifhery Eftablifhed in England, how Advantagious would it be to the Publick: When all our disbanded Soldiers, poor Prifoners, Widows and Orphans, all poor Tradefmen, Artificers and $\mathrm{La}$ bourers, their Wives, Children and Servants, each vacant Interval may be getting a Penny by braiding and beeting of Nets, Orc.

D. But ftill you want Marriners; whereas Sailors in Holland, are as Common as Beggars in England.

$E$. 'Tis own'd, our want of Marriners enough at once to Man our Navy, and Collery, coft London, and the Dependences upon the River of Thames (during the late War) above Seaven hundred thoufand Pounds, only in the Price of Conls; by which may be gueffed, how Detrimental it was to the Trade of our Nation in General. 


\section{$\left(3^{8}\right)$}

But the more we want Mariners, the greater reafon we have to eftablifh a $\mathrm{Fi}_{\text {- }}$ Jbery, which (the Preface hows) is the beft way to encreafe their number.

- The many Thoufarids, Englifh, Scotch, and Irifh Mariners, who now yearly finh for you, would hardly feek Wurk abroad, if a Filbery afforded 'em full Employment at home, and 'tis odds', but a finer Country, cheaper and better Food and Raiment, wholefomer Air, eafier Rents and Taxes, will tempt many of your Cuuntry Men to crofs the Herring Pond.

Since the Peace is concluded, and our great Ships laid up, we have Mariners enough to begin a Fiffery; and as that goes forwards, it will proportionably encreafe their numbers.

D. Fiffing is a Work for which the Eng. lifh are unfit, and requires fuch skilful, induftrious and robuft Seamen, as no Country breeds but Holland.

$E$. Your learned Keckermain fays, Om* nibus Hodiè Gentibus, Navigandi, indeit Atria er peritia Superiores effe Anglos.

'T is certain, our Mariners do as cheerfully undergo hardfhips, and are as bold in danger as any; and for hard Labour, 


\section{(39)}

the working of a Mine is incomparably harder than that of a Ship. No Country but Great Britain can boaft, that after twelve hours hard "Work, its Natives will (in the Evening) go to Foot-ball, Stool-ball, Cricket, Prifon-bafe, Wreftling, Cudgel-playing, or fome fuch vehement Exercife for their Recreations : And as for their Genius, it's remarkable is $^{2}$ that fuch Lads and Country Fellows, a.

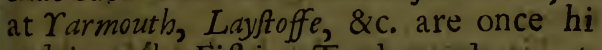
red into the Fifhing Trade, and come to feed on the Fifh they catch, it improves them at fuch a rate, that of pitiful Weaklings at Land, they become healthful, ftout and hardy Perfons, and upon trial, find it fo much to their liking, that not one in twenty, but take to the Sea for good and all.

D. Englifh Men are dainty chapt, and when a Fißhing, cannot fare like ours.

$E$. It is certain, they need not for Meat and Drink in Ireland; and in many Parts of England, are above as cheap again as in Holland, which produceth no other Provifions (for Traffick) than Butter and Cheefe; and even thole are chea. per with us than with you: Befides, 'tis obferved, that whatever Dutch Filfier- 


\section{(40)}

men fave by eating of Grout, they drink more than ours in Brandy.

D. The ACt of the is Car. 2. probibits the Importation of Irifh Cattle, to keep up Rents: Now catching much Fifls (by bindering the Confumption of Fleff) will make Lands fall.

$E$. Doubtiefs, plentfy of Food is a great Blefling, and no good Englifs : Man will delire to grow rich by a Famine.

'Tis generally the landed Men bear the Burthen of the Poor; without finding them Work, they muft maintain them Idle: Where the Poor's Rates are High, Lands will fall, and Rents be ill paid.

The cheaper Provifions are, the lefs Taxes will ferve in time of War; Houfekeeping will be lefs chargeable, and a lefs Rate maintain our Poor: But where Provifions are dear, Work and Wages will rife in proportion, to the great detriment of Husbandry, and ftop to Insprovements, which (pra tanto) will fall Rents; and raife all Manufactures, yet leffen their Confumption; both at homre and abroad, and neceflitate Mafters, for want of Vent (by turning, off their Jour- 


\section{$(41)$}

ney Men) to make whole Families of Beggars at once.

Catching much Fifh, will, morally fpeaking, render England lefs fubject to a Famine; which generally exhaufteth more of our Wealth in one Year, than War doth in two.

Catching much Fifh, will give Work to many Thoufands, of both Sexes, that now are cloathed in Rags, and (through Poverty) live only on Bread, WaterPulfe, Roots, and the like; who, when they come to have the Rewards of their Labours in their Hands, will incourage the Woollen Manufacture, by buying New Cloaths: And our Farmers by a greater Confumption of the Product of the Earth, by drinking Strong-beer, will advance the King's Excife, by increafing the number of Tenants, raife our Rents, eafe our Poor's Rates and Taxes, by helping to pay them.

Catching much Filh, will occafion the expence of much Butter, and make our Farmers run much upon Daries: The Bufinefs whereof, though performed by the fair Sex, turns to as griod Account, as the hardeft Labour the Hersbandman can imploy his Time in: Put cafe the Mar- 


\section{$\left(4^{2}\right)$}

Market fhould be over-ftock'd at Honre, Englifh Butter is too good a Conmodity in Flanders, France, Spain, Portugal, \&c. Ever to want Vent abroad.

1. The cheaper our Provifions are, the more Navigation will be encouraged; more Foreign Ships will vietual with us; fewer of ours in Ireland; and the more Beef, Pork, Ec. fhall we Export to Barbadoes, Famaica, and the reft of our Plantations: So, that fuppofing Meat hould not always remain at a very exceffive Rate, yet, where a greater Confuniption caufeth a quick Market, though at a midling Price; if the Proverb be true, Light Gains will make a heavy Purfe.

It is cheap Provifions that enables the Indians to fupplant the Europerns in their Manufactures: And thould a Fifhery make Provifions in England, but one Tenth part cheaper, Wages would fall in proportion, and our Artifts grow never the poorer; yet our Merchants be enabled (by under-felling) to beat all the reft of Europe out of the Woollen Trade, and then our Farmers would gain far more by the rife of the Fleece, than they'd lofe by the fall of the Flesh. 


\section{$(43)$}

Befides, the Profit of our Lands, doth not wholly arife from Breeding, abate in Grafing, and plow up more Pafture, and Flefs will hold its price.

D. Corn is fo cheap in Engfand, your Farmers are often Broke by it; what then could you do with greater Quantities?

$E$. The Reafon why our Farmers fometimes want Vent for their Grain, is, becaufe we have not always Store, and therefore Merchants make no Provifion for the Trade: But if we yearly fow fuch Quantities of Corn beyond the expence of the Nation, as Merchants may be no lefs certain of a conftant fupply here, than they are in the Sound (where the Country depends as much upon their Harvelt as France does on its Vintages) Plenty will foon create a. Trade, and the Advantage of England's lying fo nuch nearer than Dantzig, to the Places where Foreign Corn is Exported; together with the allowance granted by the 25 Car. 2. upon the Exporting thereof, will fufficiently encuurage Merchánts to deal therein.

Moft of our Ships are now fent light to Bilboa and Lisbon: (now what loads our Ships, helps our Navigation) And 


\section{$(44)$}

our Exports to Lisbon, not anfwering our Imports from thence: The more we fend them in Corn, the lefs their Wines will coft the Nation in ready Money, or Bills of Exchange, which is all one.

Gold and Silver Mines, England hath none, and in time of Peace no way to get Bullion, but by Foreign Traffick; to which, nothing can more conduce than cheap Fifhing, cheap Working and Manufacturing the Complodities, which compofe the Exports of our Kingdom; and hat is, not to be effected, except Labuur be cheap, which it can never be, where Provifions are dcar : But the cheaper our Provifions are, the cheaper our Exports may be afforded; confequently the more Vent we thall have for them, and much Vent will caufe many Workmen; and when the Whee is fet a going, Trade begets Trade, as Fire begets. Fire; and the more Trade encreafeth, the more will Induftrious People, from all Parts fluck to us, and tenant our Houfes, enclofe our Wafts, improve our Lands, encreafe our Manufactures, and enlarge our Products, far beyond, the whole Expence of our Nation, and thereby, in proportion, add to its Wealth and Treafure: 


\section{$(45)$}

for Merchants Exporting the Surplus, will in Returns bring back Gold, Silver, and other valuable Commodities, which (in England that hath Property) by Succeflion of Contracts, will diffufe among its Inhabitants; and thus as the number of Perfons, made rich by their Labour and Induftry, encreafe, and the choice of Tenants and Chapmen, are enlarged, a kind of Competition amongft them, muft, and will make Rents and Lands advance in proportion : Witnefs Hot land, and fuch Larıds, as lye near great and populous Corporations. So true it is, that Trade and Lands are Trins, that always wax and wain together.

D. Notwithftanding, phat bath been faid, I advife all your Country Men, not to be concerned in a Fifhery, for, in $\mathrm{Hol}$ land we bave Money at Three, whereas the Trade of England is burtbened with Six per Cent. Intereft; confequently you can never keep pace with us.

$E$. Why do you not (for the fame reafon) advife us to forbear Trading to Eaft-India, Turkey, Spain, France, Italy, Portugal, \&c. nay, to quit all Navigation, and abandon our felves to the next Comers? Was it not the Fifhises Trade gave 
gave Rife to all your Wealth; and as Money grew plentiful in Holland, did not Lands rife gradually to near Forty Years purchafe, and Intereft fall by degrees from Eight to Three per Cent? Why then may not we expect, that a Fiffsery will do the like in England; and be a means to regain our Muscovy, Greenland, Normay, and Eaft Country Trades? For, ftill as Trade by encreafing of Wealth, caufeth an abatement of intereft, abatenent of Interelt will yet caufe a further encreafe of Trade.

D. The Dutch are already fettled in the Fifbing Trade.

$E$. Stately Genoa, that once employed Forty thoufand Hands in the Silken Manufacture; declines now as faft, as her formerly neglected Neighbour Leghorn rifeth: And if the Frenchking continues to court all the World with popular Immunities, Leghorn (in tinie) nuft give place to her Silter Marfeilles.

place to King of Portugal having difcovexed the Paffage, to the Eaft Indies $(x)$, by the Cape of Good Hope, and fo diverted the Counfe of frade driven by the Kene-

(x) Anno I 500. 
from Alexandria, and the Red Sea, his. Port of Lisbon; kept Factors at trmerp, to $N$ end there his Indian Comdities; which drew feveral Merchants Fom divers Parts to refide there, and made that pleafant feated City the Packhoule of Europe: But when the Dutch (y) alfo found the way to the Indies, and began to rival Portugal in that Trade, Merchants refolving not to lofe the advantage of their Skill in Indian Commodities, by removing to Amfterdam, inbroved their own Eftates, but ruin'd Antwerp.

Trade, like the Sea, its Element often, bbbs and flows from one place to anoher: Not many Years fince, we Imported Silk Stockings from the Levant; but now the Tide is turn'd, and we fend hem thither.

D. It's too great an Undertaking.

$E$. The Flemings were long fettled in he Manufacturing of our Wooll; yet (in Edward the III. time) when the Englifs et about it themfelves, in good earneft, they effectually fixed that Rich Staple in England. The Dutch likewife for many.

(y) Anno 1602. 


\section{$\left(4^{8}\right)$}

Years after, had the Drefling and Dying of our Woollen Manufactories; but when we undertook the Work, they were loon deprived of that Advantage, which fo great Benefits our Country would have yet wanted, had all Men thought them too big to be accomplifhed.

D. Projects in England, bave of late proved very unfuccessful.

$E$. What! though fome Men have run upon wild Notions, and catching at Shadows loft their Subftance, that's no Objection againft our Fifhery, which is a certainty; for the Sea yields her Fifh, as well as the Earth her Fruit in due feafon: And Neptune hath been far more bountiful to you than Ceres.

D. Have you drawn up a Method for employing the Poor of England in a National Fifhery?

$E$. I have attenipted it, but find the well-contriving the Bufinefs, requires far better Heads than mine.

D. However let's see your E S S A Y.

E. Here it is, Sir. 


\section{(49)}

\section{THE}

\section{PROPOSAL.}

r. THA $T$ towards raifing a Joint1 ftock for Employing the Poor in a National Fifhery, a Million be Subfrribed. ,

2. That the Money Subfribed be called Stock, and be Affignable.

3. That every Subfcriber, at the time of fuch their Subfcriptions, pay to ....... One full fourth Part of his, her, or their refpective Subfcriptions; and in Default of fuch Payment, every Subfcription to be utterly Void and Null.

4. That the refidue of the faid Subfcriptions, be paid by fuch Proportions, and at fuch Days and Times, as by a General Court of the faid Subfcribers, fhall from time to time be appointed: And in Default of fuch Payment, that then the fourth Part firft paid, as aforefaid, be forfeited to the Ufe of the Corporation, herein after mentioned, their Succeffors and Affigns. 
5. That the Sublcribers be Incorporated by Act of Parliament (by the Name of the Corporation, for employing the Poor of England in a National Fijhery) with perpetual Succeflion.

6. That at a General Court to be held for the faid Corporation, Thirty be chofen out of the faid Subfcribers, by plurality of Votes, and prefented to the Parliament.

7. That out of the faid Thirty, Ten be nominated Fathers of the Poor, and Directors of the National Fifhery by both Houfes of Parliament, approved by His Majefty, and accountable to them for their-Truft.

8. That in cafe of Vacancy (by the Death, or Mifdemeanor) of any one of the faid Fathers of the Poor (during Seflions of Parliament, the faid Corporation to prefent Three, out of which His Majefty and Parliament to nominate One, as before, and fo toties quoties. But in cafe the Parliament fhall not then be fitting, that fuch Vacancies be filled up by the Majority of the Surviving Fathers until next Seffions of Parliament; and then the Corporation to prefent, and the King and Parliament to approve as before. 
9. That fuch Fathers be Impowered to Conftitute under the Seal of the faid Corporation, a fufficient Number of Deputies in each County in England; and that fuch Deputies be, and be called Stewards of the Pour.

Io. That the faid Fathers and fuch Stewards of the Poor, be exempted from all Parifh Offices.

11. That the faid Fathers, and fuch their Stewards be vefted with all Authority now in Juftices of the Peace ; and that all Parifh Officers be fubordinate and accountable to the faid (Fathers, and fuch their Stewards, ) in all things (only) relating to Employing the Poor.

r2. That the faid Fathers and Stewards have Freedom to fet the Poor on Work, about fuch of the faid Trades re. lating to the Fifhery as they fhall thiuk fit, with a non obftante to all Patents that have been, or fhall be granted.

13. That to prevent People from being oppreft, and ground to Poverty by Pawnbroakers, that forew out of them 40 or $\xi^{\circ}$ per Cent; the faid Fathers masy be allowed to erect Lumber:Offices in every City and Town in England exclufive of all o-

$$
\text { C } 2
$$

titer; 
thers, upon Condition they take not above...... per Cent. per Annum.

14. That in all Churches (as in $\mathrm{Hol}$ land) at every Solemn Affembly, the Church-Wardens with a long Staff and $\mathrm{Bag}$, during the Sermon, receive the Charitable Benevolence of the whole Congregation, and pay the fame to the faid Fathers, who thall caufe a true Account to be kept thereof, and apply it to the Erecting Hofpitals in London and $\mathrm{o}-$ ther Great Cities, wherein Poor Women near the time of their Travel, may be received and carefully Delivered, and remain till they are in a condition to return Home, and follow their Work: And if at the Years end, any Overplus of fuch Cullections remain, that the fame be Yearly applyed for Marrying poor Maids.

35. That until the Bufinefs of the Fishery be fufficient alone to give Employment to all our Poor, (or at leaft during Ten Years next after the Elt iblithing a National Fiffiery, ) the faid Fathers and Stewards of the Poor, may be Impowered to Imploy fuch of them as they fhall think fit, in ereeting Free-Schools, Hofpitals, Work-houfes, and Ware-houfes; for the Corporation, in making Enclo-

fures, 
fures, in reparing Sea Banks, draining Fens, cleanfing and deepning Rivers and Havens, in building and repairing Churches, Bridges and Caufeways, in menaing Roads, in planting Oaks near Navigable Rivers, and Fruit Trees in Inland Countries, alfo in cleanfing of Streets, Common-fhores, and the like.

16. That the faid Fathers of the Poor, be Impowered to fend fuch Refractory Poor as they fhall think fit, to ferve in His Majefties Plantations, taking Security for their comfortable Maintenance during... years Service, and for their Freedon afterwards.

17. That all the Poor's Rates in England be Collected, as formerly by the ChurchWardens of each Parin, and by them quarterly paid into the Treafury of the faid Corporation, as a Recompence for their providing for the Poor, and freeing the Nation from Beggars.

18. That the Million Subfcribed, be a1ways kept intire, as a Security to Indemnify the Nation againit the Charge of the Poor, and the Income and Profits be only divided among it the Subfribers.

19. That the Treafare of the faid Corporation be accounted as Sacred, and that $\mathrm{C}_{3}$ 
it be Felony to imbezel, lend, convert, or apply the fame to any other Ufe, than maintaining the Poor, or carrying on the Pufinefs of the Fifhery.

20. That His Majefty be Addreffed, to grant Leafes to fuch National Fifhery, of the Wafts and Direlict Lands, to be by them ufed in Building Ware - houfes Curing Fifh, Beeting, Corking, Leading and Drying Nets, Spining Twine, and the like.

21. That the faid Fathers may buy up, when Cheap, a certain Quantity of Corn, Coals, oc. yearly, and lodge the fame in Grimaries \& $W$ barfs, for the Ufe of their Poor, but not make Merchandize of them, or fell them again in England.

22. That the Stock in the faid Fiphery be not chargeable with any Rates, Duties, or Impofitions whatfoever.

23. That Debts due to the Fißsery, for Goods by them, bona fide fold and delivered, take Preference of all others, except thofe due to the King.

24. That all Perfons may Finh as formerly, and fell what they catch in England, but none Export any Fifh butthe National Fifhery without paying them .. .....per Cent. 
25. That the faid Fathers and Stewards, be Impowered to bind luch fingle Perfons to the Company, as the ChurchWardens and Overfeers of the Poor by the Statutes of ${ }_{43}$ Eliz. 2. I Fac. 25. 21 Fac. 28. and the 3 Car. 4 . are Impowr ered to put out Apprentices, the Boys to Serve till Twenty four, and the Girls till Twenty one Years of Age; at one of the two and thirty Trades more immediately relating to the Fi/hery.

The Companies Intereft will oblige them to Provide the beft and fobereft Mafters.

How to prevent their Defertion can be fhown beyond Objection.

Now fuch Apprentices being in the Fifhing Seafon enploy'd at Sed, and at other. Times in that Trade relating to the Fifhery to which they were Bound, when their Time is out, will be able to get their Livelyhoods either at Sea or Land; and if to render them more capable of ferving their Country, the faid Fathers or Stewards (at Four a Clock each Saturday in the Afternoon) fhould caufe them when (on hore) to Mufter and Exercife (although only with Staves, ) and for Diverfion to play at Cudgels or, Fence, 


\section{$\left(5^{6}\right)$}

and reward the Conquerer with liberty of wearing a fmall Ribbon, whofe diftinguifhing Colour of Red, Blem, \&c. fhould Entitle them to be called Captains, Lieutenants, \&rc. by the reft of their Fellows, till next Weeks trial of Skill : How foon would Emulation beget Addrefs? And what a Treafure and Strength to England would fuch a Militia be, always ready for Service both by Sea and Land, and yet no Charge to the Nation till actually in it.,.

Nor will fuch Lads be lefs profitable to the Corporation, for fuppofe (as ufual) the charge of Fifhing to confift $\frac{x}{3}$ in the Dogger \& Rigging, in Victuals, Nets, \&c.and $\frac{1}{3}$ in Seamens-Wages; and the whole to amount to Nine hundred Pounds.

Admitting our Craft, Rigging and Victualing, as Chargeable as the Dutch, and that they amount together to $600 \mathrm{l}$. Then $300 \%$ remains for Wages.

Should the Corporation the firft Year, have but $\frac{x}{3}$ of a Dogger's-Crew their own Servants, (bating what is paid more to Officers till their own Apprentices are fit to Command, ) it will fave them one of the faid $300 \mathrm{l}$. and if the next Year the Corporation have the $\frac{x}{2}$ of their Doggers-Crew 


\section{$(57)$}

sers-Crew their Apprentices, it will then ave them $150 \mathrm{l}$. of the faid $300 \mathrm{l}$. and thus their Fin would ftand them the firft Year in about Ten, and the next in near Fifteen per Cent. lefs than the Dutch, and lo Proportionable to the Numbers of their Servants, their Profits will encreafe; till at length, paying little or no Wages, they may afford to fell Fifn to the Hollanders cheaper than they can catch them.

D. Money is fcarce in England.

$E$. The greater the Dearth, the mope Care fhould be had to Seed the Ground, leaft the Famine encreafe: The more our Wealth is Exhaufted, the greater Caufe have we to lay hold on the Fifllery, which (as hath been fhown ) to much Enrich'd Holland, and by parity of Reafon will bundantly add to our Treafure.

D. Upor the robole, I coinfess, its polfiole for England to out Fifs us, but then you must bave nothing to do with Companies, only make it every particular Man's Intereft, and they'l Soon make it their Bufine]s.

$E$. It's Dangerous taking a Rivals Advice, and well known why $F_{\text {iff }}$ was fo Cheap this Year in Spain, Portugal, Italy, ind other Englifh Markets; yet fold fo well in the Eaft Countries.

Glutting 


\section{$(58)$}

Glutting Markets may Ruine particu lar Men, but its far more Difficult to pu fuch Tricks upon Companies.

D. After all, where can you find Set of Honeft Men, to carry on a Nation? Fifhery in England?

E. In Amfterdam, you have you Church-wardens, Directors of Betblem, 0 your Rafp-houfe, of your Spin-houfe, od Commiffioners for your fmall Differen ces, and thofe of your Levant Trade, you Sea Affitirs, ơc. alfo your Vroedfchan your Schepens, and your Burge-mafter: which are Places of far more Troubl than Profit, yet (being the ufual fteps $t$ Preferment) are generally (like that of Common-Councit-Men in London) offici ated without Reproach. Not for that th Dutch are honefter Men than thei Neighbours: But becaufe fuch as are foun tardy in thofe Employments, are barre all future hopes of Advancement. An nhould our Parliament Addrefs his Majs Ay to prefer in the Cuftom-houfe, Excife occ. luch as behaved themfelves well i the Fifhery, and make breach of Tru therein, to incapacitate Men from fervin the Government in any Employmer Military, or Civil for ..... Yeat 


\section{$(59$.}

how fmall Wages foever the Corporation allowed, ) the Company would never want honeft Servants, who, Voluntier like, would vie with each other, who fhould beft ferve their Country by moft promoting its Fifhery.

D. An Honeft Man is a Citizen of the World, Gain equalifeth all Placcs to me. And when you fettle a Fifhery upon better Terms than our's (as my Grandfatber left Antwerp when its Trade began to decay, and removed to Amfterdan ) I'le bid ahieu to $\mathrm{t}^{\prime}$ Vaderlandt, and Remove to London. In the Interim, Faremel.

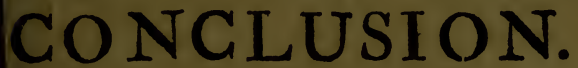

Eeing in the Peeamble of an $A C T$ $D$ paffed in the ${ }_{4} 4$ Car 2. 'Tis declaed, That the Fublick Honous, chealth and $\Rightarrow$ afete of this direalm, 5 well in the 9 aintenance and supj2t of קavigation, as in manp ofbet Refpetts, oth in an bigh \$Degzee oeno upon the 3 mpzobement ano denuragement of the FISHERY. 


\section{(60)}

And reeing the way to all this $H_{0}$ nour, Wealth and Safety is fo Plair and Eafie, that by only a Frugal and Indu?trious management of Affaris (witbout quarrelling. with our Neigbliows, we may quickly become fole Mafters o. the Fifhing Trade.

For Sbame let not Englifh-men lon(L) ger fay, with Solomon's floath fi Prov.6.13. There is a LYON
in the Way.

KOIZU.TDKOD

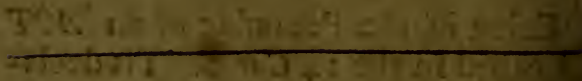

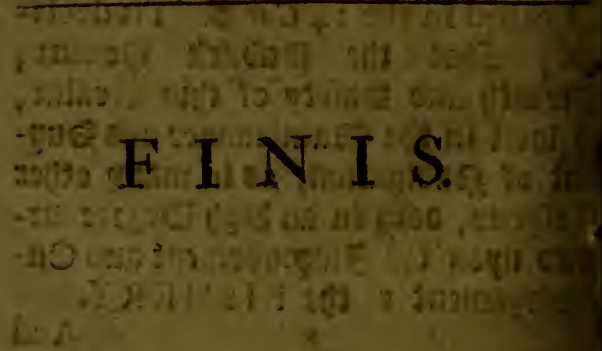



